\title{
Metabolic and Ruminal Fluid Markers of Dairy Cows Supplemented with a Combination of Yeast Culture and Hydrolyzed Yeast ${ }^{*}$
}

\author{
Tatiele Mumbach ${ }^{1}$, Raquel Fraga e Silva Raimondo², Claudia Faccio Demarco', Vanessa Oliveira Freitas', \\ Rodrigo Chaves Barcellos Grazziotin', Andressa Stein Maffi', Fernanda Medeiros Gonçalves ${ }^{3}$, \\ Cassio Cassal Brauner', Carolina Bespalhok Jacometo ${ }^{4} \&$ Marcio Nunes Corrêa'
}

\begin{abstract}
Background: In order to reduce the effects of a negative energy balance, some measures have been taken into account in nutritional management during the transition period. The use of yeast, has been a good alternative used to improve the rumen metabolism and helping the adjustment of the microbiotato the new diet. The aim of the study was to evaluate the effects of supplementing a combination of yeast culture and hydrolyzed yeast on the metabolism of dairy cows during the transition period.

Materials, Methods \& Results: The experiment was conducted in a semi-extensive system, using 20 Holstein cows, divided equally into a control group (CG) and a supplemented group (SG). The SG received $28 \mathrm{~g} / \mathrm{animal} / \mathrm{day}$ of a combination of yeast culture and hydrolyzed yeast from $20 \pm 2$ days pre-calving until early lactation ( $18 \pm 3$ days). Serum concentrations of non-esterified fatty acids (NEFA), albumin and urea were determined at calving, and for three time points during the early postpartum period and three time points during the early lactation period. Regarding energy metabolism, prepartum concentrations of NEFA were higher than the physiological standard in both groups. However, NEFA, albumin and urea decreased during the early postpartum period in the supplemented animals and could be attributed to the yeast in enhancing ruminal microorganisms' cellulolytic capacity, increasing fibre digestibility and starch utilization.

Discussion: The increased concentration of non-esterified fatty acids (NEFA) due to the mobilization of fat deposits that happens in the transition period, especially in the postpartum period reflects the cow's adaptation to the negative energy balance (NEB). The lower concentrations of NEFA observed in the present study could be attributed to the effect of the yeast in enhancing the ruminal microorganisms' cellulolytic capacity. The control cows had a BCS within the recommended range while the supplemented group had it close to the minimal limit proposed for this period. Thus, supplemented cows lost less BCS during the early postpartum period, had a lower BCS loss during the experimental period and had lower NEFA concentration that the CG. It was possible to observe a difference in serum albumin and urea between treatments only in the postpartum period. Besides showing no significant effect in BCS on prepartum period, control cows had a BCS within the recommended range while the supplemented group had it close to the minimal limit proposed for this period. Cows with high BCS prepartum had higher plasma NEFA before and after calving. It can be observed in the present study in both groups. However, a positive effect in prevent subclinical disorders might be attributed to YC, since the SG showed low NEFA plasma levels compared to the CG. Thus, supplemented cows lost less BCS during the early postpartum period, had a lower BCS loss during the experimental period and had lower NEFA concentration that the CG. There is a negative correlation between BCS and NEFA in the early postpartum period and this information explains the results observed in the present study where BCS declines in the SG are followed by a NEFA increase. This is not so marked in the $\mathrm{CG}$, indicating that SG supplementation can act by improving digestibility. Yeast supplementation promotes higher output energy, enhancing postpartum performance in dairy cows. Yeast supplementation showed benefits in early lactation compared to the prepartum and early postpartum periods, suggesting that supplementation has to have an adaptation period to be effective in protein synthesis. In conclusion, supplementation with a combination of yeast culture and hydrolyzed yeast to cows during the transition period can positively influence the energy and protein metabolism, reducing the collateral effects of negative energy balance.
\end{abstract}

Keywords: Saccharomyces cerevisiae, NEFA, rumen bacterial, dairy cows, negative energy balance.

*Article based on a Thesis submitted by the senior author in partial fulfilment of requirements for the Master's Degree. ${ }^{1}$ Núcleo de Pesquisa Ensino e Extensão em Pecuária (NUPEEC), Faculdade de Veterinária, Universidade Federal de Pelotas (UFPel), Pelotas, RS, Brazil. ²Núcleo Ruminação, ensino, pesquisa e extensão em ruminantes, Faculdade de Veterinária, Universidade Federal do Rio Grande do Sul (UFRGS), Porto Alegre, RS. ${ }^{3}$ Núcleo de Gestão Ambiental da Produção Animal, Curso Superior de Tecnologia em Gestão Ambiental, UFPel, Pelotas. ${ }^{4}$ Programa de Zootecnia, Facultad de Ciencias Agropecuarias, Universidad de La Salle, Bogotá DC, Colombia. CORRESPONDENCE: M.N. Corrêa [marcio.nunescorrea@ gmail.com - Tel.: +55(53) 3275 7136]. Núcleo de Pesquisa Ensino e Extensão em Pecuária (NUPEEC), Faculdade de Veterinária, UFPel. Campus Universitário Capão do Leão. CEP 96010-900 Pelotas, RS, Brazil. 


\section{INTRODUCTION}

From three weeks prepartum until three weeks postpartum, [14] an abrupt increase in the energy demand associated with a decrease in dry matter intake (DMI) occurs, added to stressful factors associated with calving [13].Some tools can be applied in this specific stressful period of dairy cows. The use of yeasts, especially Saccharomyces cerevisiae has been adopted as an alternative to enhancing the ruminal environment promoting digestibility efficiency and increasing DMI [10].

Dry yeast has high concentration of viable cells [22] and is a product of natural fermentation, composed of yeast cell walls ( $\beta$-glucans and mannan oligosaccharide - MOS). When the yeast cellular wall is enzymatically hydrolyzed, MOS and $\beta$-glucans are released, becoming blended with a rich supply of fermentation metabolites from the culture of $S$. cerevisiae on a defined nutrient media. Therefore, the combination of yeast culture and hydrolyzed yeast can leverage the action of the cellular wall components and enriches the product, compared to those that contain only yeast culture. The $\beta$-glucans found in the cellular wall of $S$. cerevisiae can contribute to an improvement in an animal's metabolic function, as well as a stimulator of the immune response.

In this sense, nutritional management tools could be adopted in order to reduce the effects of the NEB and promote better health status in dairies. The aim of this study was to evaluate the supplementation effects of a combination of yeast culture and hydrolyzed yeast of $S$. cerevisiae on blood metabolic biomarkers and the ruminal fluid composition of dairy cows during the transition period.

\section{MATERIALS AND METHODS}

The study was conducted on a commercial farm located at Rio Grande, RS, Brazil ( $32^{\circ} 16^{\prime} \mathrm{S}, 52^{\circ}$ $\left.32^{\prime} \mathrm{W}\right)$. The cows were maintained in a semi-extensive management system, which was based on pasture and concentrate supplementation after each milking. Milking was performed twice a day, at $12 \mathrm{~h}$ intervals.

\section{Animals, experimental design and treatments}

Twenty Holstein cows were selected according to the number of lactations ( 2 to 4 lactations) and allocated equally in two groups: the control group (CG, $\mathrm{n}=10)$ and the supplemented group $(\mathrm{SG}, \mathrm{n}=10)$. All cows were managed together during the experimental period and received the same basic diet (Prepartum: ryegrass hay and concentrate. Early Postpartum: ryegrass haylage and concentrate. Early Lactation: ryegrass hay, corn silage, concentrate and sorghum). The SG received $28 \mathrm{~g} / \mathrm{animal} /$ day of a Saccharomyces cerevisiae yeast culture blended with a hydrolyzed yeast (YC-EHY,Celmanax $\left.{ }^{\circledR}\right)^{1}$. The supplementation was performed individually and daily from $20 \pm 2$ days prepartum until $18 \pm 2$ days postpartum. Each cow was observed at the time of supplementation in order to ensure complete intake.

The animal's nutritional management comprised three balanced diets for each period according to NRC [23]: the prepartum diet (20 \pm 2 days prepartum until calving), early postpartum period (from calving until $15 \pm 3$ days) and early lactation period (from 15 to $18 \pm 3$ days postpartum). The diets had the forage : concentrate ratio modified in each period due to the increase in concentrate inclusion, as follows: Prepartum 66.67:33.33; early postpartum 44.03:55.97; early lactation 39.61:60.39.

\section{Blood sampling, analysis and BCS evaluation}

Blood samples were taken in the three different periods, according to diet changes: one sampling in prepartum (day $7 \pm 2$ ); three consecutive samplings at 24,48 and $72 \mathrm{~h}$ on early postpartum; and three consecutive samplings at 24, 48 and $72 \mathrm{~h}$ after diet changing ( $15 \pm 3$ days after calving) in the early lactation period. Blood samples were collected by coccygeal venepuncture using $10 \mathrm{~mL}$ vaccutainer tubes without a clot activator, centrifuged for $15 \mathrm{~min}$ at $1,500 \mathrm{x} g$ and the serum harvested and stored in $1.5 \mathrm{~mL}$ tubes at $-80^{\circ} \mathrm{C}$ for further biochemical analysis.

The non-esterified fatty acids (NEFA) concentration was measured through a commercial kit (kit Wake NEFA-HR) ${ }^{2}$ according to the method described by Ballou et al. [5] at days 7 prepartum, at the $24 \mathrm{~h}$ sampling of the early postpartum period and at $24 \mathrm{~h}$ sampling of the early lactation period. The protein metabolism was evaluated by measuring the serum concentrations of urea and albumin by colorimetric analysis using a commercial kits ${ }^{3}$. All readings were performed BioEspectro ${ }^{4}$. The body condition score (BCS) was evaluated in the beginning of each experimental period (pre partum, post-partum and early lactation). 
Statistical analysis

Statistical analysis for NEFA, BCS, albumin and urea data were performed using the $\mathrm{SAS}^{\circledR} 9.0$ program $^{5}$. Data were checked for normality. Results were presented as mean \pm SEM. For the early postpartum and early lactation periods, data were presented as a mean of the three consecutive samplings for each group. ANOVA with repeated measures and means comparisons by the Tukey-Kramer test were used in a MIXED MODELS mode, having as fixed effects the groups (supplemented vs. control), time and its interaction. Statistically significant differences were defined as $P \leq 0.05$.

\section{RESULTS}

Prepartum concentrations of NEFA were higher than the physiological standard, while concentrations of $0.04 \mathrm{mmol} / \mathrm{L}$ in the prepartum period and 0.7 $\mathrm{mmol} / \mathrm{L}$ in the postpartum period are desirable in dairy cows [27]. No statistically significant differences were detected, the cows from the control group had double the desirable concentration for this period.

The positive effect of yeast supplementation during the transition period on NEFA concentration (Figure 1) was observed in the early postpartum period $(P=0.047)$.

No significance BCS differences were observed on prepartum period (Figure 2), besides showing no statistically significant differences, it was possible to observe a 0.7 points BCS reduction in the $\mathrm{CG}$ while the SG lost 0.5 points during the whole experimental period.

Was possible to observe a difference in serum albumin and urea between treatments only in the postpartum period (Figures 3,4). During the early postpartum period, both groups had albumin concentrations lower than the recommended level $(2.47 \pm 0.06 \mathrm{~g} / \mathrm{dL}$ and $2.48 \pm 0.06 \mathrm{~g} / \mathrm{dL}$, in the $\mathrm{SG}$ and CG respectively). Yeast supplementation decreased albumin concentrations during the early lactation period $(2.31 \pm 0.08$ $\mathrm{g} / \mathrm{L}$ and $2.56 \pm 0.08 \mathrm{~g} / \mathrm{L}$ in $\mathrm{SG}$ and $\mathrm{CG}$ respectively).

Urea concentrations levels effect was observed during the early lactation period (Figure 4), with low concentrations for the SG $(14.40 \pm 1.17 \mathrm{mg} / \mathrm{dL})$ compared to the $\mathrm{CG}(18.53 \pm 1.19 \mathrm{mg} / \mathrm{dL})$.

\section{DISCUSSION}

The increased concentrations of NEFA due to the mobilization of fat deposits that happens in the transition period, especially in the postpartum period, is justified for increased milk production in specialized dairy cows and reflects the cow's adaptation to the NEB [14].During this period there was an expected increase in the NEFA concentration related to the prepartum period in the SG, which was close to the recommended value, $0.7 \mathrm{mmol} / \mathrm{L}$, [27]. On the other hand, the NEFA concentration in the CG was higher than the recommended level, reflecting a mobilization of body fat deposits. When the fat mobilization overloads the liver oxidation capacity ketone bodies are synthesized, promoting further metabolic disorders [3]. The lower concentrations of NEFA observed in the SG in the early postpartum period could be attributed to the effect of the yeast in enhancing the ruminal microorganisms' cellulolytic capacity, increasing fibre digestibility and starch utilization [11]. Consequently there is a lower conversion and efficiency of feed nutrients for milk production during the transition period, without the necessity of mobilizing the fat tissue deposits used as an energy source during the NEB [21]. So, the yeast supplementation performed in this study contributed positively, reducing the NEFA concentrations. NEFA decreases were also observed by [3] in dairy cows supplemented with yeast culture in the early postpartum period, justifying this effect by an enhancement in ruminal function and ruminal VFA increase [1].

Besides showing no significant effect in BCS on prepartum period (Figure 1), control cows had a BCS within the recommended range while the supplemented group had it close to the minimal limit proposed for this period. BCS evaluation is a cheap and useful strategy to minimize postpartum subclinical ketosis, for instance [16]. Cows with high BCS prepartum had higher plasma NEFA before and after calving [6]. It is possible to see this situation in the present study in both groups. However, a positive effect in prevent subclinical disorders might be attributed to $\mathrm{YC}$, since the $\mathrm{SG}$ showed low NEFA plasma levels compared to the CG.

Busato et al. [8] compared cows that had different BCS prepartum and its losses during the postpartum and concluded that cows with BCS $>3.25$ in the prepartum lost more than 0.75 points of BCS, mobilized a greater quantity of fat, and consequently had higher NEFA concentrations two weeks postpartum related to other groups $(\mathrm{BCS}>3.25$ prepartum lost $\leq 0.75$ after calving; BCS 3.25 prepartum lost $\leq$ 0.75 after calving; and BCS $\leq 3.25$ prepartum lost $>$ 0.75 after calving). Thus, supplemented cows lost less 
NEFA

${ }^{*} P=0.0469$

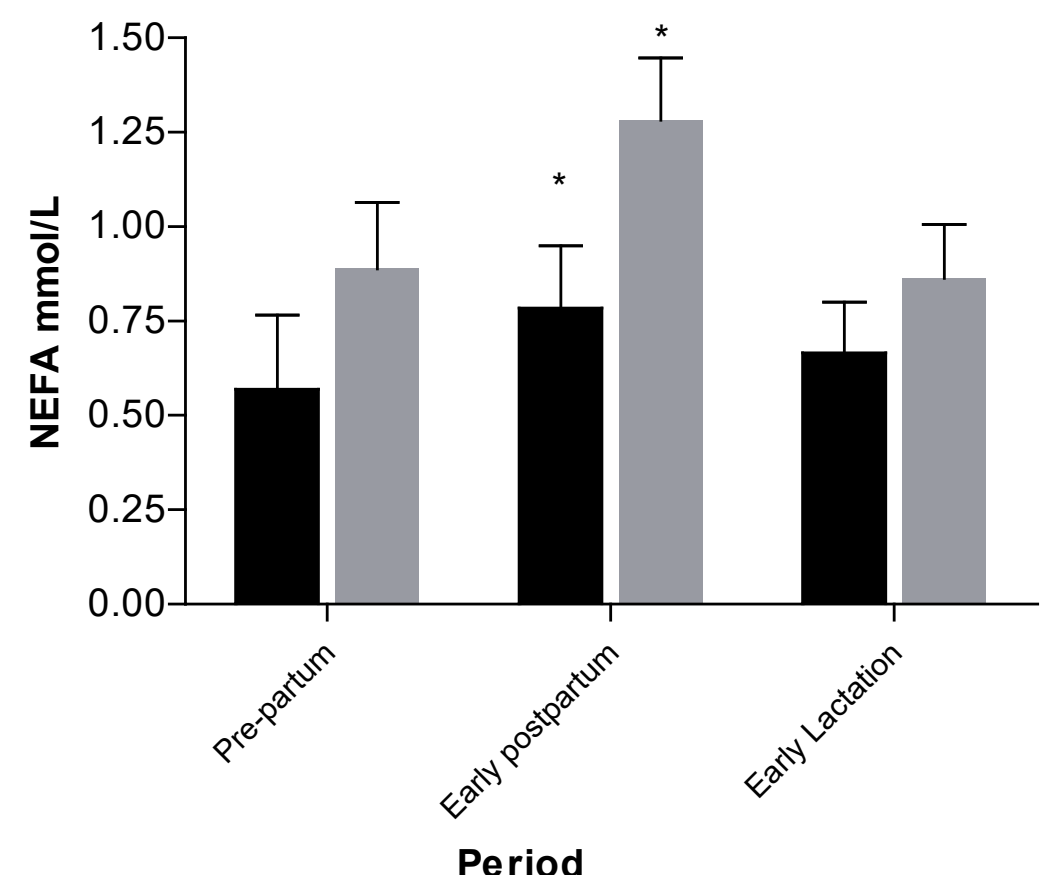

- Supplemented $\square$ Control

Period

Figure 1. Mean \pm SEM of non-esterified fatty acids (NEFA) levels (mmol/L) of dairy cows supplemented with a combination of yeast culture and hydrolyzed yeast during the transition period. Asterisks indicate significant $(* P<0.05)$ differences in supplemented group versus control group.

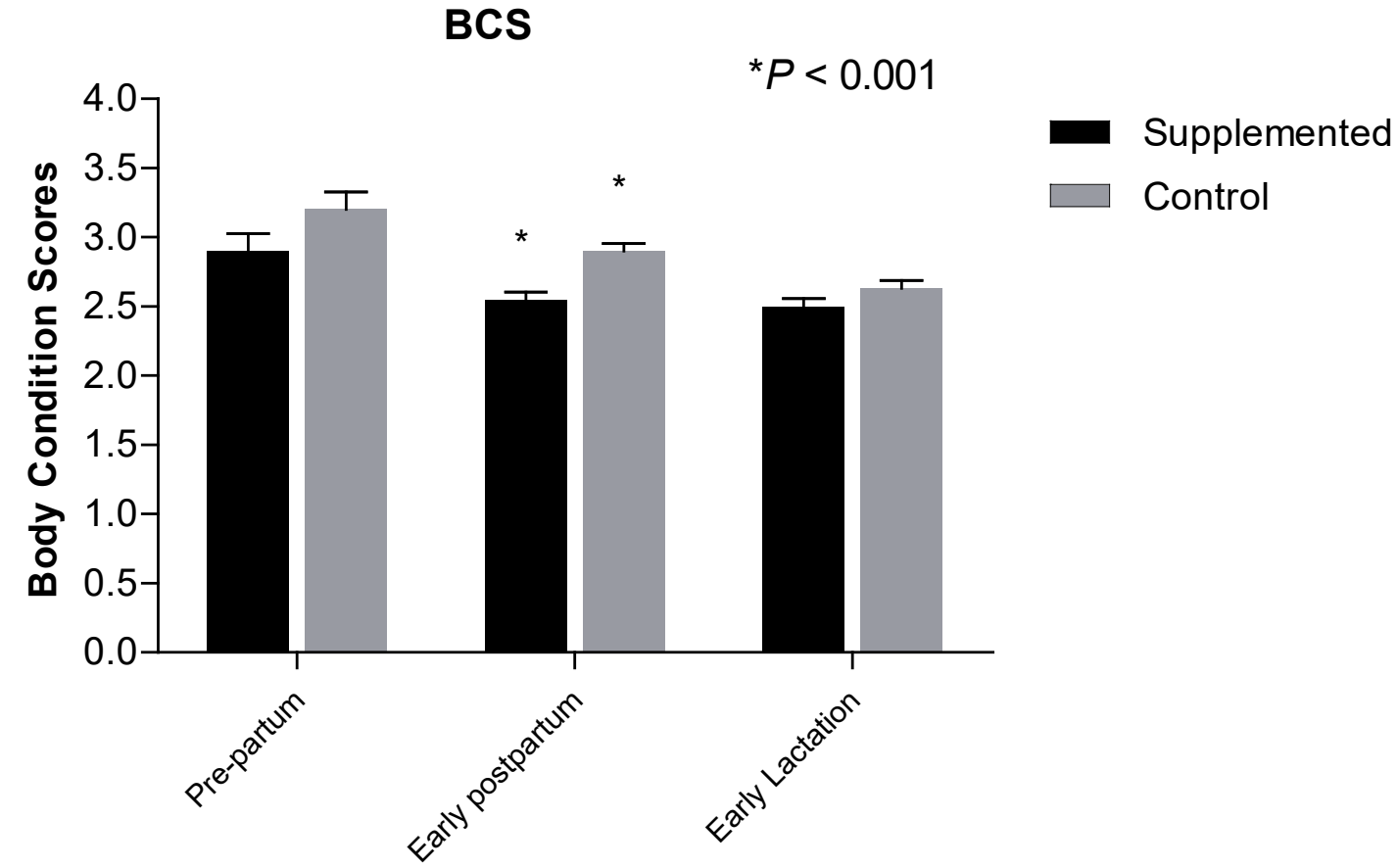

Period

Figure 2. Body condition score (BCS) of dairy cows supplemented with a combination of yeast culture and hydrolyzed yeast during the transition period. Asterisks indicate significant $(* P<0.05)$ differences in supplemented group versus control group. 


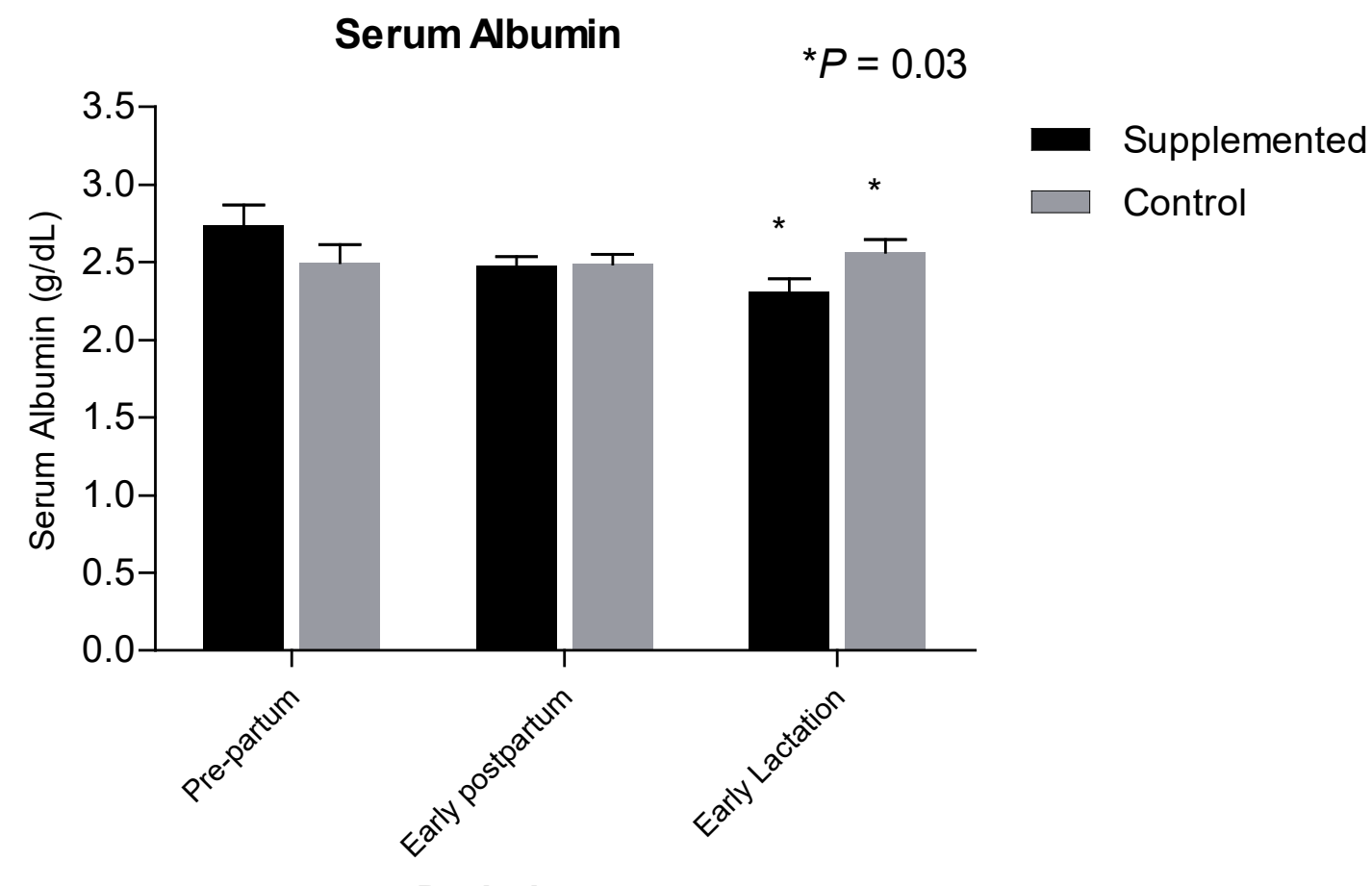

Period

Figure 3. Mean \pm SEM of Serum Albumin (g/dL) concentration of dairy cows supplemented with a combination of yeast culture and hydrolyzed yeast during the transition period. Asterisks indicate significant $(* P<0.05)$ differences in supplemented group versus control group.

\section{Serum Urea}

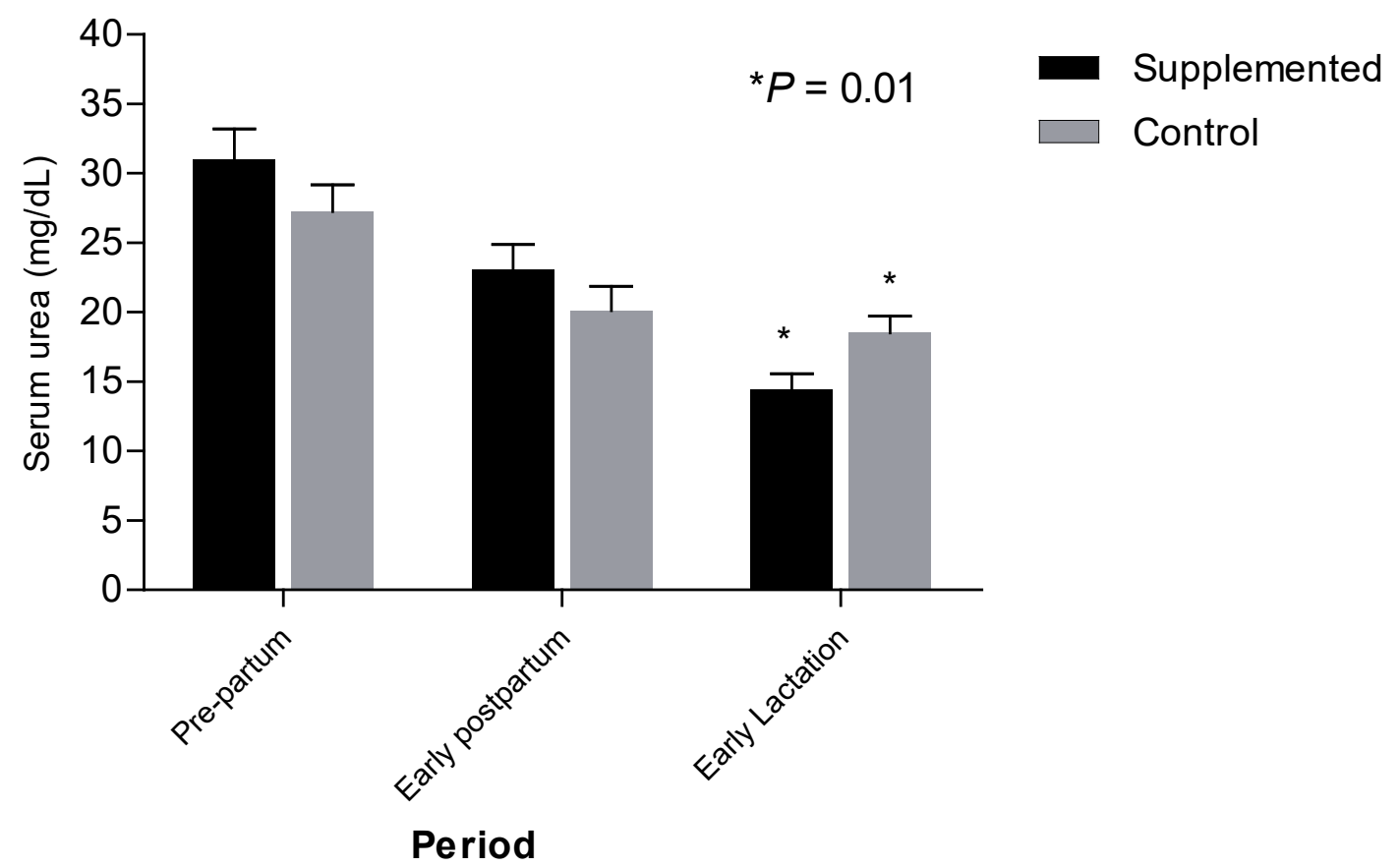

Figure 4. Mean \pm SEM of Serum Urea (mg/dL) concentration of dairy cows supplemented with a combination of yeast culture and hydrolyzed yeast during the transition period. Asterisks indicate significant $(* P<0.05)$ differences in supplemented group versus control group. 
BCS during the early postpartum period, had a lower BCS loss during the experimental period and had lower NEFA concentration that the CG.

Body condition score can be a critical effect in dairies during the transition period, which is marked by a depression in DMI intake, due to an advancing gestation, and consequently BCS reduction and weight loss on the early postpartum, [24]. BCS reduction in early postpartum is a physiological mechanism, observing BCS and body weight loss in dairies from -30 days to 30 days postpartum [6].

The same results was found by Al Ibrahim et al. [2] comparing yeast supplementation of dairy cows with high or low $\mathrm{BCS}(\mathrm{BCS} \leq 3.5$ and $\mathrm{BCS} \geq 3.75)$ assuming that yeast supplementation has no effect in DMI and thus in the BCS. According to Petrera et al.[25] there is a negative correlation between BCS and NEFA in the early postpartum period and this information explains the results observed in the present study where BCS declines in the SG are followed by a NEFA increase. This is not so marked in the CG, indicating that SG supplementation can act by improving digestibility. Yeast supplementation promotes higher output energy, enhancing postpartum performance in dairies [28].

During the early postpartum period, both groups had albumin concentrations lower than the recommended level $(2.47 \pm 0.06 \mathrm{~g} / \mathrm{dL}$ and $2.48 \pm 0.06$ $\mathrm{g} / \mathrm{dL}$, in the $\mathrm{SG}$ and $\mathrm{CG}$ respectively).Concentrations varying from 2.7 to $3.8 \mathrm{~g} / \mathrm{dL}$ of albumin are considered ideal for dairy cows [19]. So, the results in this trial could be related to a diversion of serum proteins, mainly albumin and $\mathrm{IgG}$, to the udder at the end of pregnancy for colostrum synthesis [18].

Yeast supplementation decreased albumin concentrations during the early lactation period (2.31 $\pm 0.08 \mathrm{~g} / \mathrm{L}$ and $2.56 \pm 0.08 \mathrm{~g} / \mathrm{L}$ in SG and CG respectively). Low concentrations of antibacterial components and serum albumin, as well as high concentrations of casein, lactose, and citrate, are characteristic of mammary secretions at two weeks before calving [26]. Those parameters are influenced by intramammary infections [30], suggesting that yeast culture enhanced immunization system in pre calving stage. Ayad et $a l$.[4] did not find an effect of yeast culture supplementation in albumin concentration, except at days 30 and 45 postpartum, when the supplemented group had higher concentrations. Yeast supplementation is capable of increasing serum protein due to stimulation of rumen microbes, changing protein synthesis and increasing protein passage [17]. The early lactation period is marked by a physiological drop levels in serum proteins [20], suggesting that yeast supplementation can stimulate protein synthesis in dairy cows [9]. Urea concentrations were kept between the standards (15$40 \mathrm{mg} / \mathrm{dL}$ ) in both groups in the prepartum and early postpartum periods, A high blood concentration of urea can be indicative of an inefficient use of crude dietary protein [7]. Yeast supplementation can increase this efficiency due a positive effect on growth and activity of proteolytic ruminal bacteria [15].

The reduction in the ruminal ammonia concentration reflects higher microbial protein transport, and its flux from rumen to duodenum, thereby contributing to lower concentrations of ruminal ammoniacal nitrogen [29].

Dolezal et al. [12] attribute the low blood urea in yeast supplemented animals to a by-pass protein effect in the rumen or a lower concentration of ruminal degradable protein.

Yeast supplementation showed benefits in early lactation compared to the prepartum and early postpartum periods, suggesting that supplementation has to have an adaptation period to be effective in protein synthesis.

\section{CONCLUSIONS}

Supplemented dairy cattle with a combination of yeast culture and hydrolyzed yeast during the transition period might change metabolism markers in a positive way, reducing the collateral effects of negative energy balance.

\section{MANUFACTURERS}

${ }^{1}$ Arm \& Hammer Animal Nutrition. Princeton, NJ, USA.

${ }^{2}$ Wako Chemicals USA Inc. Richmond, VA, USA.

${ }^{3}$ Labtest Diagnóstica S.A. Belo Horizonte, MG, Brazil.

${ }^{4}$ Microtécnica Equipamentos para Laborátorio. Curitiba, PR, Brazil. ${ }^{5}$ SAS Institute Inc. Cary, NC, USA.

Funding. This research was supported by Conselho Nacional de Desenvolvimento Científico e Tecnológico (CNPq), and partly financial support by Arm and Hammer Animal Nutrition.

Ethical approval. All procedures, treatment sand animal care were in compliance with the Ethics Committee on Animal Experimentation of the Federal University of Pelotas, and the research was registered and approved under the number 6040 .

Declaration of interest. The authors report no conflicts of interest. The authors alone are responsible for the content and writing of paper. 


\section{REFERENCES}

1 Al Ibrahim R.M., Gath V.P., Campion D.P., McCamey, C., Duffy P. \& Mulligan F.J. 2012. The effect of abrupt or gradual introduction to pasture after calving and supplementation with Saccharomyces cerevisiae (Strain 1026) on ruminal $\mathrm{pH}$ and fermentation in early lactation dairy cows. Animal Feed and Science Technology. 178(1-2): 40-47.

2 Al Ibrahim R.M., Kelly A.K., O'Grady L., Gath V.P., McCamey C. \& Mulligan F.J. 2010. The effect of body condition score at calving and supplementation with Saccharomyces cerevisiae on milk production, metabolic status, and rumen fermentation of dairy cows in early lactation. Journal of Dairy Science. 93(11): 5318-5328.

3 Al Ibrahim R.M., Whelan S.J., Pierce K.M., Campion D.P., Gath V.P. \& Mulligan F.J. 2013. Effect of timing of post-partum introduction to pasture and supplementation with Saccharomyces cerevisiae on milk production, metabolic status, energy balance and some reproductive parameters in early lactation dairy cows. Journal of Animal Physiology and Animal Nutrition. 97(Suppl 1): 105-114.

4 Ayad M.A. Benallou B., Saim M.S., Smadi M.A. \& Meziane T. 2013. Impact of feeding yeast culture on milk yield, milk components, and blood components in Algerian dairy herds. Journal Veterinary Science and Technology. 4(2): 135-140.

5 Ballou M.A., Gomes R.C., Juchem S.O. \& Depeters E.J. 2009. Effects of dietary supplemental fish oil during the peripartum period on blood metabolites and hepatic fatty acid compositions and total triacylglycerol concentrations of multiparous Holstein cows. Journal of Dairy Science. 92(2): 657-669.

6 Bernabucci U., Ronchi B., Lacetera N. \& Nardone A. 2005. Influence of body condition score on relationships between metabolic status and oxidative stress in periparturient dairy cows. Journal of Dairy Science. 88(6): 2017-2026.

7 Broderick G.A. \& Clayton M.K. 1997. A statistical evaluation of animal and nutritional factors influencing concentrations of milk urea nitrogen. Journal of Dairy Science. 80(11): 2964-2971.

8 Busato A., Faissler D., Kupfer U. \& Blum J.W. 2002. Body condition scores in dairy cows: associations with metabolic and endocrine changes in healthy dairy cows. Journal of Veterinary Medicine. 49(1): 455-460.

9 Denev S.A., PeevaTz., Radulova P., Stancheva N., Staykova G., Beev G., Todorova P. \& Tchobanova S. 2007. Yeast cultures in ruminant nutrition. Bulgarian Journal of Agricultural Science. 13(1): 357-374.

10 Desnoyers M., Giger-Reverdin S., Bertin G., Duvaux-Ponter C. \& Sauvant D. 2009. Meta-analysis of the influence of Saccharomyces cerevisiae supplementation on ruminal parameters and milk production of ruminants. Journal of Dairy Science. 92(4): 1620-1632.

11 Dolezal P., Dolezal J. \& Trinacty J. 2005. The effect of Saccharomyces cerevisiae on ruminal fermentation in dairy cows. Czech Journal of Animal Science. 50(1-3): 503-510.

12 Dolezal P., Dvoracek J., Dolezal J., Cermakova J., Zeman L. \& Szwedziak K. 2011. Effect of feeding yeast culture on ruminal fermentation and blood indicators of Holstein dairy cows. ActaVeterinaria Brno. 80(2): 139-145.

13 Drackley J.K., Dann H.M., Douglas G.N., Guretzky N.A.J., Litherlans N.B., Underwood J.P. \& Loor J.J. 2005. Physiological and pathological adaptations in dairy cows that may increase susceptibility to periparturient diseases and disorders. Italian Journal of Animal Science. 4(1): 323-344.

14 Duffield T.F. \& LeBlanc S.J. 2009. Interpretation of serum metabolic parameters around the transition period. In: Proceedings of the Southwest Nutrition and Management Conference (Ontario, Canada). pp.106-114.

15 Fonty G. \& Chaucheyras-Durand F. 2006. Effects and modes of action of live yeasts in the rumen. Biologia. 61(6): 741-750.

16 Garro C.J., Mian L. \& Cobos Roldán M. 2014. Subclinical ketosis in dairy cows: prevalence and risk factors in grazing production system. Journal of Animal Physiology and Animal Nutrition. 98(5): 838-844.

17 Iwanska S., Strusinska D. \& Zalewski W. 1999. The effect of Saccharomyces cerevisiae 1026 used alone or with vitamin-mineral premix on biochemical parameters of blood and milk in dairy cows. Acta Veterinaria Hungarica. 47(1): 53-63.

18 Jain N.C. 1993. Essentials of Veterinary Hematology. New York: Wiley-Blackwell, 417p.

19 Kaneko J.J., Harvey J.W. \& Bruss M.L. 2008. Clinical biochemistry of domestic animals. 6th edn. San Diego CA: Academic Press, 916p.

20 Levieux D. \& Ollier A. 1999. Bovine immunoglobulin G, $\beta$-lactoglobulin, $\alpha$-lactalbumin and serum albumin in colostrum and milk during the early postpartum period. Journal of Dairy Research. 66(3): 421-430.

21 Lopuszanska-Rusek M. \& Bilik K. 2011. Influence of pre- and postpartum supplementation of fibrolytic enzymes and yeast culture, or both, on performance and metabolic status of dairy cows. Annals of Animal Science.11(4): 531-545. 
22 Nocek J.E., Holt M.G. \& Oppy J. 2011. Effects of supplementation with yeast culture and enzymatically hydrolyzed yeast on performance of early lactation dairy cattle. Journal of Dairy Science. 94(8): 4046-4056.

23 NRC 2001. Nutrient requirements of dairy cattle. 7th edn. Washington DC: National Research Council, National Academy of Science, 408p.

24 Park A.F., Shirply J.E., Titgemeyer E.C., Defrain J.M., Cochran R.C., Wickersham E.E., Nagaraja T.G. \& Johnson D.E. 2011. Characterization of ruminal dynamics in Holstein dairy cows during the periparturient period. Journal of Animal Physiology and Animal Nutrition. 95(5): 571-582.

25 Petrera F., Napolitano F., Dal Prà A. \& Abeni F. 2014. Plasma parameters related to energy and lipid metabolism in periparturient Modenese and Italian Friesian cows. Journal of Animal Physiology and Animal Nutrition. 99(5): 962-973.

26 Pezeshki A., Capuco A.V., De Spiegeleer B., Peelman L., Stevens M., Collier R.J. \& Burvenich C. 2010. An integrated view on how the management of the dry period length of lactating cows could affect mammary biology and defence. Journal of animal physiology and animal nutrition. 94(5): e7-30.

27 Promkot C., Mansathit J. \& Wanapat M. 2011. Metabolic Disorders of Transitional Low Production Dairy Cow. Journal of Agricultural Science and Technology. A1: 1221-1223.

28 Robinson P.H. \& Garrett J.E. 1999. Effect of yeast culture (Saccharomyces cerevisiae) on adaptation of cows to postpartum diets and on lactational performance. Journal of Animal Science. 77(4): 988-999.

29 Santra A. \& Karim S.A. 2003. Rumen manipulation to improve animal productivity. Asian-Australasian Journal of Animal Science. 16(5): 748-763.

30 Shamay A., Homans R., Fuerman Y., Levin I., Barash H., Silanikove N. \& Mabjeesh S.J. 2005. Expression of albumin in non-hepatic tissues and its synthesis by the bovine mammary gland. Journal of Dairy Science. 88(2): 569-576. 